Hydrology and Earth System Sciences, 8(6), 1193-1199 (2004) C) EGU

\title{
Research Note:
}

\section{An approach to integrated assessement of reservoir siltation: the Joaquín Costa reservoir as a case study}

\author{
A. Navas ${ }^{1}$, B. Valero Garcés ${ }^{2}$ and J. Machín ${ }^{1}$ \\ ${ }^{1}$ Estación Experimental de Aula Dei \\ ${ }^{2}$ Instituto Pirenaico de Ecología del CSIC, RICTA, Apartado 202, 50080 Zaragoza, Spain \\ Email for corresponding author: anavas@eead.csic.es
}

\begin{abstract}
In 1932, the Esera river was dammed at the foothills of the Pyrenean External Ranges; since then, sedimentation has reduced its water storage capacity by a third. This study of the sediments in the Joaquín Costa reservoir has been based on detailed sedimentological examination and other analysis of mineralogy, grain size distribution and the chemical components of the materials accumulated at the bottom of the reservoir. Interpretations are based on results from four sediment cores collected at sites representative of the main environments in the reservoir. Records of known flood events and of reservoir management data have been combined with a ${ }^{137} \mathrm{Cs}$-derived chronology. Thus, it has been possible to ascribe the sedimentary record at the different reservoir environments to specific years, as well as some main changes in the facies types and sediment components. This methodology is a first approach to assessing siltation processes and dynamics in Mediterranean mountain reservoirs.
\end{abstract}

Keywords: reservoir siltation, mineralogy, sedimentology,sedimentation rates, ${ }^{137} \mathrm{Cs}$, sediment tracing, mountain reservoir, central Spanish Pyrenees

\section{Introduction}

To improve the management of hydrological resources, many rivers in Spanish basins have been dammed; siltation of these Mediterranean mountain reservoirs is a significant problem on which little information is available. Furthermore, the scarcity of water resources demands sound management based on reliable data within a context of resource sustainability.

The sediment supply to the Joaquín Costa reservoir, part of a system of ten large dams impounding rivers in the central Spanish Pyrenees, is related to both snowmelt and storm events. A bathymetric survey (CEDEX, 1995) estimated the annual average sediment entering the reservoir to be around $350 \mathrm{t} \mathrm{km}^{-2}$.

In this study, multidisciplinary data have been combined to reconstruct the history of siltation to derive information on the sedimentation dynamics in the reservoir system. Sedimentological, mineralogical, chemical and flood data, determined from four sediment cores collected along the reservoir's axis, have been combined with radioisotopic data to characterise the siltation and depositional processes in the reservoir. This integrated approach addresses the problem of siltation in reservoirs in Mediterranean environments.

\section{Methodology}

THE JOAQUÍN COSTA RESERVOIR

In 1932, the Esera river was dammed at Graus (central Spanish Pyrenees). The reservoir (6 km long, $1 \mathrm{~km}$ wide) follows the submerged and meandering Esera channel. With an average depth of $16 \mathrm{~m}$ increasing to a maximum of $60 \mathrm{~m}$ at its outlet, its initial storage capacity was $92 \times 10^{6} \mathrm{~m}^{3}$ (Fig. 1). After the confluence with the Isábena river, the annual inflow to the reservoir of about $845 \times 10^{6} \mathrm{~m}^{3}$ is largely from the Esera river. The main environments in the reservoir are the delta area at the mouth of the river, the submerged plains and the dam wall delta (Valero Garcés et al., 1997). 


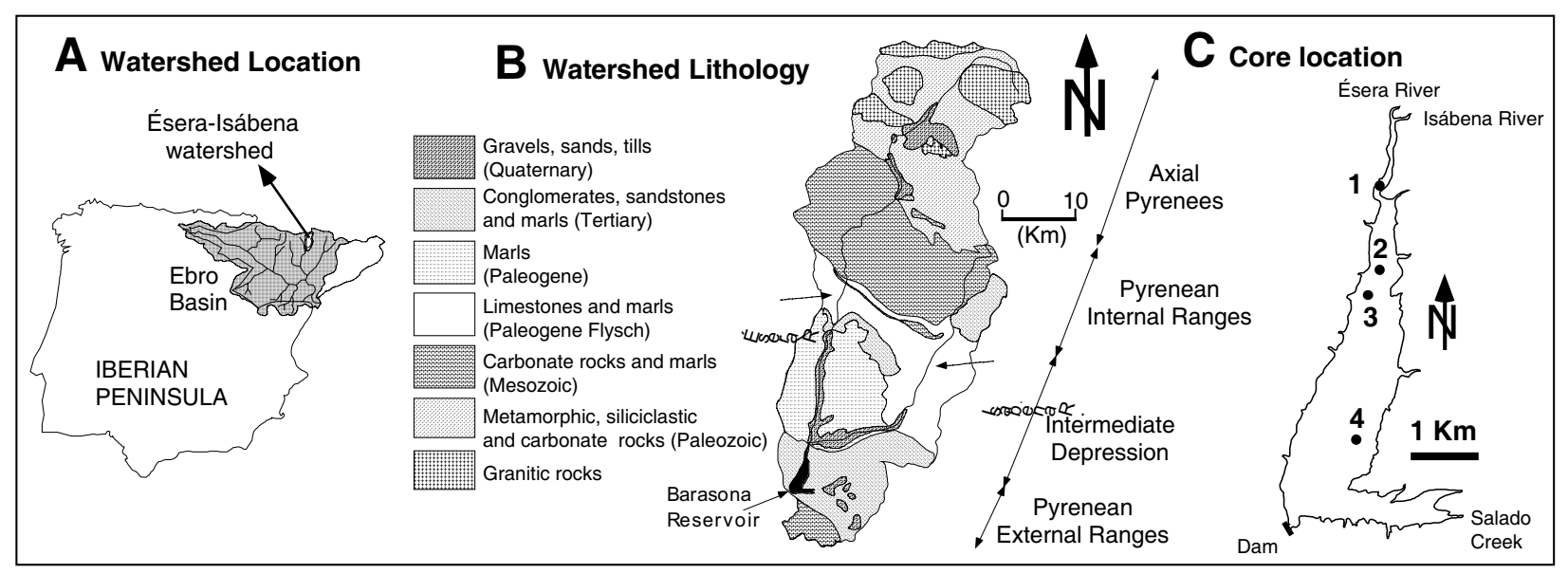

Fig. 1. (A) Location of the Joaquin Costa reservoir in the Central Spanish Pyrenees within the Ebro basin.

(B) Lithology and main structural units in the Esera-Isábena watershed.

(C) Location of the four sediment cores collected in the main environments of the reservoir following its axis downward from the delta mouth to the delta dam.

The Esera river drains a large and heterogeneous basin $\left(1224 \mathrm{~km}^{2}\right)$ and flows $\mathrm{N}-\mathrm{S}$, dissecting a very diverse lithology that varies from granite and other metamorphic, siliciclastic and carbonate Paleozoic rocks in the axial part, followed by calcareous Mesozoic rocks in the Internal Ranges, and then Tertiary limestones, marls, conglomerates and sandstones in the Intermediate Depression and the External Ranges. The Internal Ranges have been identified as the main contributors to sediment delivery in the basin. High erosion rates were measured in badlands of this area and a load of $500000 \mathrm{~m}^{3}$ reaches the reservoir each year (Fargas et al., 1996). In agreement with this, Valero Garcés et al. (1996) also measured the highest concentration of suspended sediments transported by the Esera river in the Internal Ranges in relation to both the outcropping of more erodible materials as well as a much larger agricultural area.

\section{SEDIMENT CORES, SAMPLE PREPARATION AND ANALYSES}

The main environments in the reservoir are the delta area at the mouth of the river, the submerged plains and the dam wall delta (Valero Garcés et al., 1997). The four cores analysed in this study were taken in the bottom deposits along the reservoir's longest axis along the submerged Esera channel (Fig. 1). They were selected from 22 cores used to characterise in detail the sedimentary environments in the reservoir. The core depths varied from $2 \mathrm{~m}$ to more than $6 \mathrm{~m}$ and the intention to collect the entire deposit at each selected site was achieved at three of the four sites when the typical red fluvial facies of the Esera river comprising gravel and sand was reached. The complete sequence at site
3 was not recovered and should include around $60 \mathrm{~cm}$ more of reservoir facies.

Core 1 is $205 \mathrm{~cm}$ deep and corresponds to the delta mouth environment. Core 2, $200 \mathrm{~cm}$ deep, corresponds to the northern area of the submerged plains. Core 3 (240 cm deep) is at the central part of the submerged plains. Core 4, 600 $\mathrm{cm}$ deep, is located at the southern part of the submerged plains at their widest extension in the reservoir. To differentiate the sediments accumulated in the reservoir bottom, an additional core (control core C, $80 \mathrm{~cm}$ deep) was collected some $300 \mathrm{~m}$ south of Core 3 at the coast line; this represented a littoral environment. Cores 1, 2 and 3, did not exceed $2.5 \mathrm{~m}$, and were taken by a mechanically driven core driller. Core 4 was retrieved using a hand operated piston-coring device, a modified Livingstone corer.

Sediments in the cores were extruded to study and describe their characteristics, such as lithology, colour, grain size, transition changes and sedimentary structures. Cores were sectioned for the various analyses. Samples were placed in plastic bags for storage and kept refrigerated for laboratory processing and analysis. They were air-dried and ground to pass through a $2 \mathrm{~mm}$ sieve. The chemical analyses included carbonate content by calcimetric techniques and organic matter content by loss on ignition at $450^{\circ} \mathrm{C}$. Mineralogical analyses were performed using a Siemens D-500 diffractometer working at $40 \mathrm{kv}$ and $30 \mathrm{~mA}$. Semiquantitative results of the mineralogical percentages were obtained using relative reflectance factors. Granulometric analysis of different size fractions used Malvern and Coulter laser equipment after particles were chemically disaggregated and dispersed ultrasonically. ${ }^{137} \mathrm{Cs}$ activity was measured in 146 sediment samples by gamma spectrometry. 
A total of 72 grab samples was collected across the reservoir in a grid pattern, during a bathymetric survey in 1995 by the CEDEX, to assess the spatial distribution of the grain size of surface sediments by geostatistical interpolation.

Flow records at the gauging stations upstream of the reservoir entrance were obtained from the Water Authority (Confederación Hidrográfica del Ebro).

\section{Results and discussion}

\section{FACIES AND SEDIMENT COMPOSITION}

The grain size distribution of the surface sediments follows that expected for deposition in reservoirs. The coarser fractions are closer to the river outlet where tractive mechanisms are predominant. Conversely, the finer fractions accumulate at the delta dam where the water table is deeper and a lacustrine regime of transport and deposit is operating. Over most of the area of the reservoir, the sand content is less than 5\%; only in the delta mouth does it exceed $40 \%$. The highest sand content occurs at the Esera and Isábena outlets $(>80 \%)$ and at the SE bay which is fed by some ephemeral creeks. Silt, the predominant fraction in the surface sediments, ranges from $40 \%$ to less than $80 \%$ but for most of the reservoir area it exceeds $60 \%$. The clay fraction is also abundant and over most of the reservoir the surface sediments contain $20-30 \%$ of clay, with a maximum $(>40 \%)$ at the delta dam.

The sediment cores taken at the reservoir are representative of its main sediment environments and the sedimentological facies are shown in Fig. 2. In cores 1, 2
Core 1
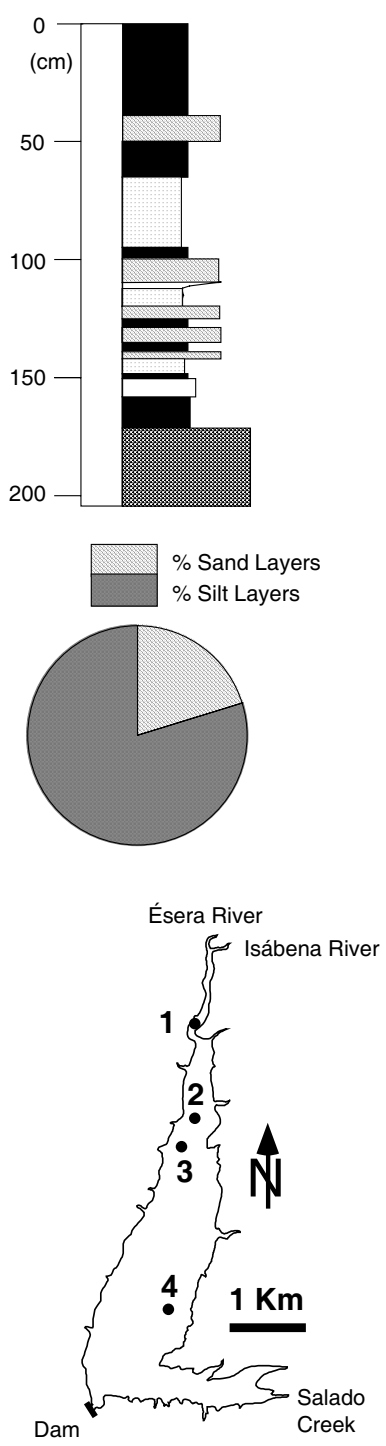

Core 2

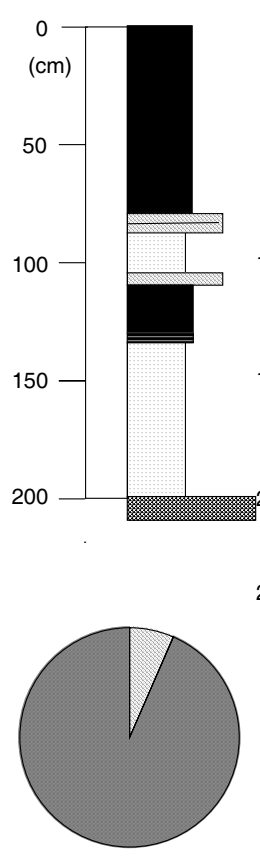

Core 3

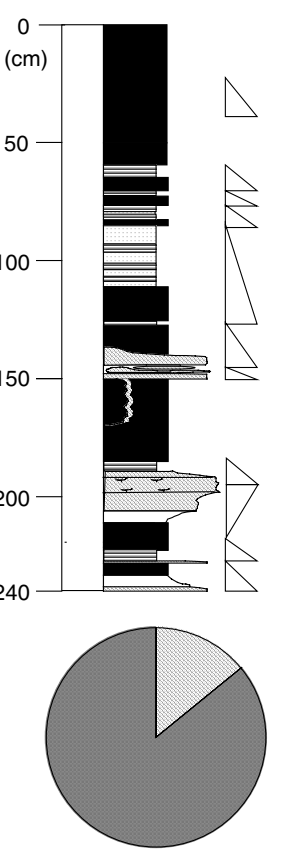

LEGEND

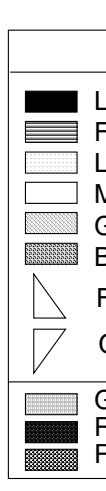

\section{Facies}

Laminated fine grey silt Finely laminated, fine black silt Laminated, variegated silt

Massive coarse grey silt

Grey sands and silty sand

Brown sands and silty sand

Fining-upward sequences

Coarsening-upward sequences

Grey silt

Red silt
Red gravel and sand
Core 4

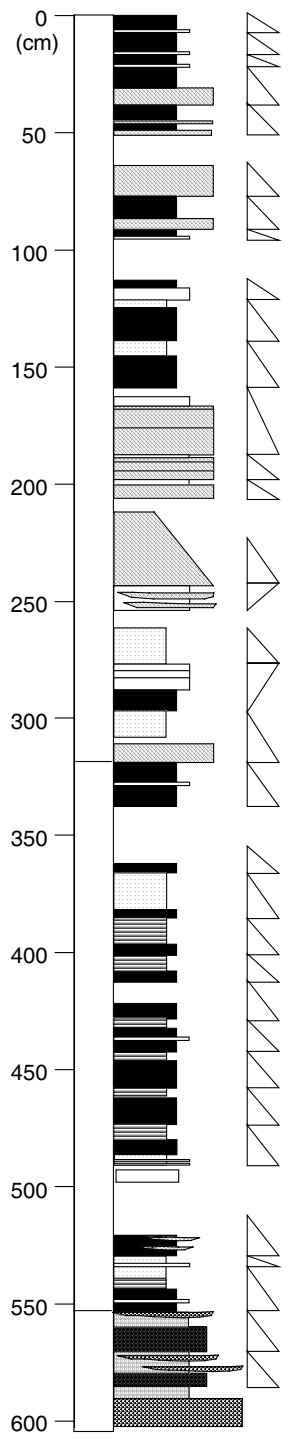

Fig. 2. Sedimentary facies and percentages of silt and sand layers in the four cores of the Joaquin Costa reservoir. 
and 3 corresponding to the delta mouth and the northern and central submerged plains respectively, silt layers account for more than $80 \%$, while sand layers are from 7-14\% except at the delta mouth, where they may reach $20 \%$. As expected from the sedimentation dynamics in reservoirs, the thickness of the deposit increases towards the delta dam (core 4), where the water level is highest and where most of the facies are preserved because subaerial exposure during low water levels is less frequent in this area. Although silt layers are the more abundant (54\%), percentages of sand layers account for almost half of the entire deposit in the southern submerged plains.

When comparing the distribution of the sedimentary facies, sand layers are clearly more abundant in the lower half of cores 1,2 and 3; exceptionally, in core 4, sand layers predominate in the upper half, perhaps because of the regimes operating in the different areas of the reservoir and of the occurrence of floods during low or high levels of water in the reservoir.

The results of mineralogical analysis of the cores selected show calcite as most abundant (30-40\%), followed by clay minerals (25-30\%) and quartz (20-30\%). Minor components are feldspar and dolomite (less than 5\%). The most abundant clays are illites, chlorites and kaolinites, in that order; also, some pyrophyllites are found (Valero Garcés et al., 1999).

Granulometrical analyses (Fig. 3) in cores 1 and 2 present very similar grain size distributions, suggesting that the delta mouth and the northern submerged plains are sedimentologically similar. Higher percentages of sand appear in the lower parts of cores 2 and 3, while just the opposite happens in core 4 . The variations in grain size distribution agree with the pattern of mineral distribution and support the identification of two contrasting periods in the sedimentary record of this reservoir.

Chemical analysis of core samples quantified the percentages of organic matter, carbonates and other inorganic (non-carbonate) components. Table 1 shows that organic matter content is low but increases towards the delta dam, peaking at $6 \%$ in core 4 . The carbonate content, similar in cores 1 and 2, almost doubles in cores 3 and 4. Conversely, the content of inorganic (non-carbonate and silicate)

\section{Core 1}
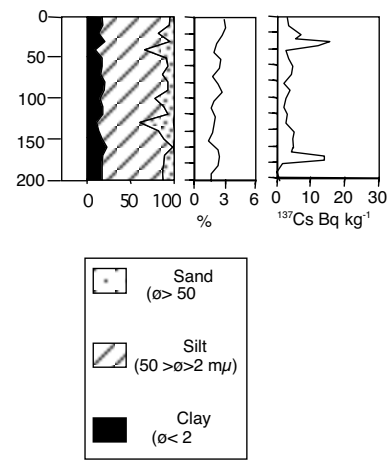

Core 2

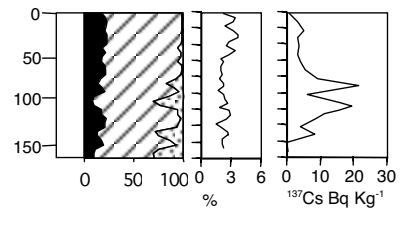

Core 3

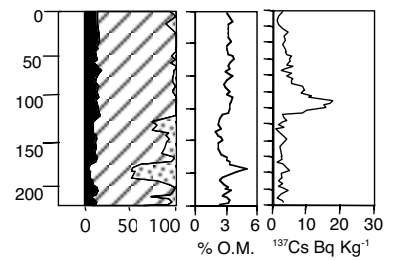

Core 4

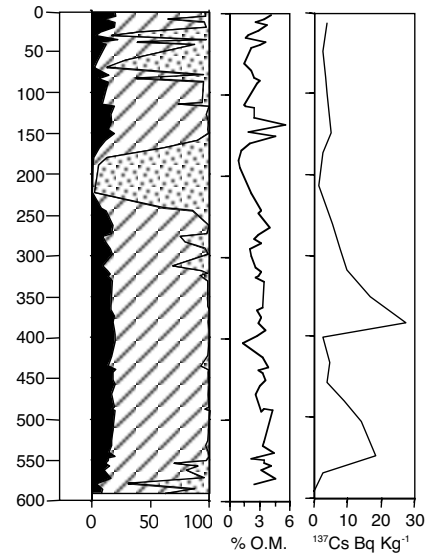

Fig. 3. Distribution of grain size and organic matter percentages and ${ }^{137}$ Cs activity curves in the sediments of the four cores in the reservoir.

Table 1. Basic statistics (\%) of the main organic and inorganic components in the four cores collected along the axis of the reservoir.

\begin{tabular}{|c|c|c|c|c|c|c|c|c|c|c|c|c|c|c|c|c|}
\hline & \multirow[b]{2}{*}{$n$} & \multirow[b]{2}{*}{ ave. } & \multicolumn{4}{|c|}{ Organic matter } & \multirow[b]{2}{*}{ ave. } & \multicolumn{3}{|c|}{ Carbonates } & \multirow[b]{2}{*}{$C V$} & \multicolumn{5}{|c|}{ Silicates and non-carbonates } \\
\hline & & & $\max$ & $\min$ & s.d. & $C V$ & & $\max$ & $\min$ & s.d. & & ave. & $\max$ & $\min$ & s.d. & $C V$ \\
\hline Core 1 & 21 & 2.20 & 3.04 & 1.41 & 0.47 & 21 & 18.38 & 21.09 & 12.36 & 2.28 & 12 & 79.52 & 85.00 & 77.00 & 2.16 & 3 \\
\hline Core 2 & 34 & 2.55 & 3.76 & 1.61 & 0.55 & 22 & 18.00 & 20.88 & 13.38 & 1.74 & 10 & 79.46 & 84.31 & 77.04 & 1.80 & 2 \\
\hline Core 3 & 60 & 3.08 & 5.07 & 1.96 & 0.53 & 17 & 38.13 & 48.00 & 26.00 & 4.63 & 12 & 58.75 & 70.46 & 49.12 & 4.42 & 8 \\
\hline Core 4 & 68 & 2.85 & 6.00 & 1.00 & 0.97 & 34 & 36.18 & 48.00 & 22.00 & 5.72 & 16 & 60.99 & 74.00 & 51.00 & 5.34 & 9 \\
\hline
\end{tabular}


components is very high in the delta mouth and northern submerged plains and decreases down the reservoir axis in cores 3 and 4 .

The most distinctive features in the cores are the variations in organic matter content, generally associated with the finer fractions of clay minerals (Fig. 3). The organic matter increases in the upper halves of cores 1,2 and 3 while a marked decrease occurs in the upper half of core 4 . This is paralleled by a decrease in the inorganic components and an increase in carbonates. Because of the calcareous composition of the sands, the highest carbonate contents occur in the sandy intervals as in the upper part of core 4.

\section{THE SEDIMENTATION IN THE RESERVOIR}

The chronology of the sediment sequence deposited at the Joaquín Costa reservoir has been reconstructed by ascribing the main sedimentological features to the known floods (Table 2) or to other characteristics, such as the functioning of the reservoir, and by combining these data with the chronology derived from the ${ }^{137} \mathrm{Cs}$ radiotracer.

The use of ${ }^{137} \mathrm{Cs}$ to trace sediment movement and deposition has been referenced in the literature (Ritchie and McHenry, 1990; Foster and Walling, 1994; Navas et al., 1998). Accumulation rates can be derived by comparing the vertical distribution of ${ }^{137} \mathrm{Cs}$ in sediment profiles with the history of its fallout from the atmosphere (Cambray et al., 1983). From the ${ }^{137} \mathrm{Cs}$ fallout, only two dates, 1954, the year of its first appearance, and 1963, the year of its maximum accumulation, can be determined in most of the sediment profiles (Whicker et al., 1994).

In the control core $\mathrm{C},{ }^{137} \mathrm{Cs}$ was present, not in the deeper horizons of the red fluvial facies in the coast line but only in the first $5 \mathrm{~cm}\left(1.6 \mathrm{~Bq} \mathrm{~kg}^{-1}\right)$; this allowed discrimination between fluvial and reservoir facies.

Figure 3 shows that ${ }^{137} \mathrm{Cs}$ peaks occur at different depths in all the cores. At the delta mouth, the peak at 170-180 cm in core 1 has been ascribed to 1963 . Therefore, since the reservoir was built in 1932, until the early 1960s, only 30$40 \mathrm{~cm}$ of sediments were deposited at this site. It may be that accumulated sediments were evacuated by annual flushes of the reservoir. Since 1963, around $170 \mathrm{~cm}$ of sediment accumulated at this site so that the rate of sedimentation at the delta mouth from 1963 to 1996 was $5.2 \mathrm{~cm} \mathrm{yr}^{-1}$. A second ${ }^{137} \mathrm{Cs}$ maximum close to the surface of the cores may reflect remobilisation of sediment; at the mouth of the delta, the energy of floods is highest and tractive mechanisms are predominant. It appears that erosion and remobilisation of accumulated sediments occurred at this site. The relatively low sedimentation rate can also be explained by the predominance, from the 1960s, of late
Table 2. Discharge and main floods recorded at the reservoir entrance.

\begin{tabular}{|c|c|c|c|}
\hline Year & Discharge $\left(\mathrm{Hm}^{3}\right)$ & Date & Flow $\left(\max m^{3} s^{-1}\right)$ \\
\hline 1934 & & $01-05-34$ & 484 \\
\hline 1950 & & $18-05-50$ & 486 \\
\hline 1951 & 953.94 & $30-05-51$ & 821 \\
\hline 1952 & 407.78 & $29-05-52$ & 763 \\
\hline 1953 & 608.83 & $29-06-53$ & 309 \\
\hline 1954 & 720.09 & $14-10-54$ & 472 \\
\hline 1955 & 1001.77 & $07-06-55$ & 547 \\
\hline 1956 & 516.44 & $07-08-56$ & 726 \\
\hline 1957 & 594.61 & $03-06-57$ & 360 \\
\hline 1958 & 693.92 & $25-03-58$ & 516 \\
\hline 1959 & 1551.47 & $04-03-59$ & 539 \\
\hline 1960 & 1096.00 & $15-07-60$ & 1069 \\
\hline 1961 & 1264.75 & $04-10-61$ & 843 \\
\hline 1962 & 1134.23 & $07-03-62$ & 980 \\
\hline 1963 & 1462.48 & $03-08-63$ & 821 \\
\hline 1964 & 679.27 & $16-11-64$ & 1210 \\
\hline 1965 & 1019.73 & $30-09-65$ & 556 \\
\hline 1966 & 817.19 & $06-11-66$ & 701 \\
\hline 1967 & 774.21 & $09-03-67$ & 612 \\
\hline 1968 & 1198.19 & $17-11-68$ & 621 \\
\hline 1969 & 718.89 & $23-06-69$ & 947 \\
\hline 1970 & 1044.99 & $11-01-70$ & 557 \\
\hline 1971 & 1091.72 & $21-05-71$ & 808 \\
\hline 1972 & 765.55 & $29-06-72$ & 859 \\
\hline 1973 & 799.91 & $21-05-73$ & 556 \\
\hline 1974 & 731.69 & $17-09-74$ & 546 \\
\hline 1975 & 514.39 & $31-05-75$ & 563 \\
\hline 1976 & 1180.88 & $29-05-76$ & 438 \\
\hline 1977 & 960.26 & $02-05-77$ & 881 \\
\hline 1978 & 744.54 & $22-10-78$ & 675 \\
\hline 1979 & 538.08 & & \\
\hline 1980 & 493.81 & $11-10-80$ & 445 \\
\hline 1981 & 709.65 & & \\
\hline 1982 & 651.97 & 04-06-82 & 562 \\
\hline 1983 & 611.51 & & \\
\hline 1984 & 746.46 & & \\
\hline 1985 & 573.76 & $09-11-85$ & 613 \\
\hline 1986 & 602.24 & & \\
\hline 1987 & 961.90 & & \\
\hline 1988 & 436.60 & & \\
\hline 1989 & 481.63 & & \\
\hline 1990 & 464.08 & & \\
\hline 1991 & 569.29 & & \\
\hline 1992 & 634.10 & & \\
\hline 1993 & 659.50 & & \\
\hline 1994 & 535.04 & & \\
\hline 1995 & 1090.75 & & \\
\hline
\end{tabular}


autumn floods that enter the reservoir at its low water level. The ${ }^{137} \mathrm{Cs}$ activity curve for core 2 shows a broad peak between 90 to $130 \mathrm{~cm}$ depth. The sharp decrease in ${ }^{137} \mathrm{Cs}$ concentration at $100 \mathrm{~cm}$ is associated with the low clay content in the predominantly coarse materials deposited here by the 1963-1964 floods. At this site, $90 \mathrm{~cm}$ of sediments have accumulated since the 1963 maximum, at an average rate of $2.6 \mathrm{~cm} \mathrm{yr}^{-1}$. Before the $1963{ }^{137} \mathrm{Cs}$ peak, only around $70 \mathrm{~cm}$ of sediment was deposited at a rate of $2.3 \mathrm{~cm} \mathrm{yr}^{-1}$.

The thickness of the peak may indicate that ${ }^{137} \mathrm{Cs}$ has undergone mixing and/or diffusion. Davis et al. (1984) indicated that ${ }^{137} \mathrm{Cs}$ can be remobilised when organic matter decomposes. Moreover, some authors (e.g. Zucker et al., 1984) point out that attachment of ${ }^{137} \mathrm{Cs}$ to some clay minerals may be not permanent. Nevertheless, because this ill-defined peak has been found only in this core, it is plausible that reworking and mixing of sediments has occurred, especially in relation to the floods between 1960 1964, the most intense of all those recorded in the basin. As with core 1, the small amount of sedimentation at this site could be due to lack of deposition or erosion of sediments as fluvial processes dominated in the northern part of the submerged plains.

At the central submerged plains, a well defined ${ }^{137} \mathrm{Cs}$ peak appears in core 3 at $110-120 \mathrm{~cm}$. Above the $1963{ }^{137} \mathrm{Cs}$ peak, $110 \mathrm{~cm}$ of sediments accumulated and, therefore, the sediment rate increased slightly $\left(3.2 \mathrm{~cm} \mathrm{yr}^{-1}\right)$. It is not possible to disaggregate the complete sedimentary record because of the lack of the entire deposit that could contain the first appearance of ${ }^{137} \mathrm{Cs}$ in 1954 . Beneath the 1963 maxima to the bottom of the reservoir, $120 \mathrm{~cm}$ of sediment accumulated at this site. Although remobilisation may be predominant in this area of the reservoir, this increase in sediment can be interpreted as transitional between a fluvial regime and a lacustrine regime.

In the southern area of the submerged plains, in core 4, the ${ }^{137} \mathrm{Cs}$ activity curve peaks at $330-391 \mathrm{~cm}$ and again at $537-557 \mathrm{~cm}$, corresponding to 1963 and 1954 respectively. On the basis of this chronology, only about $33 \mathrm{~cm}$ of red and grey silts were deposited here since the dam was built in 1932 until the mid 1950s. Thereafter, annual flushes were stopped, so that the southern areas of the reservoir were submerged permanently. Taking into account the sediment thickness $(164 \mathrm{~cm})$ between the first appearance of ${ }^{137} \mathrm{Cs}$ and the main peak, the average sedimentation rate from 1954-1963 was highest $\left(18.2 \mathrm{~cm} \mathrm{yr}^{-1}\right)$. The scarcity of sandy silt layers suggested that floods were less frequent or intense during this period or that they occurred when reservoir levels were high. According to data from water authorities (Table 2 ), the annual inflow into the reservoir was highest in the mid 1950s-1960s; consequently, higher reservoir level should be expected. During the last three decades, almost $4 \mathrm{~m}$ of sediment accumulated at the site of core 4 , with an average sedimentation rate of $11.6 \mathrm{~cm} \mathrm{yr}^{-1}$ and sandy sediments were more abundant. The predominance of coarser materials above the 1963 horizon agrees with the maximum autumn flood frequency registered from the 1960s and supports the hypotheses that at the lowest water level in the reservoir, floods could reach the southern areas where sediments would be deposited.

All these data indicate that between 1932 and 1954 and in all the areas of the reservoir from the delta mouth to the southern submerged plains, erosion and remobilisation were the main sedimentary processes to transport the sediments out of the reservoir. It also appears that, in general, the highest water level in the reservoir, occurring between the mid 1950s-1960s, favoured the accumulation of sediments in the southern areas rather than in the northern and delta mouth areas, where coarser materials accumulated as the less frequent floods reached the reservoir at high water levels. Since 1963, erosion is still predominant in the northern areas of the reservoir and at the delta mouth where, despite the increase in flood frequency, little sediment accumulated. In an intermediate position, the central submerged plains accumulated more sediments, albeit transitionally because erosion was still important, while in the southern submerged plains, sediments were deposited in a lacustrine regime.

\section{Conclusions}

The sediments accumulated in the reservoir during the 65 years of impoundment are supplied mainly by riverine inputs during periods of maximum flow. A transitional regime towards a lacustrine type is established as the axial distance from the delta mouth increases with the depth of water. Hence, the functioning of the reservoir depends on the depth of water that makes the tractive mechanisms of sediment transport by the Esera channel predominant during the low water levels and, conversely, the suspended transport and deposition by decantation of fine particles at times of high water levels.

Combination of the various sedimentological and analytical techniques applied in this study allowed the main episodes of erosion and accumulation within the Joaquín Costa reservoir to be related to documented events. This methodology permitted the main processes in the siltation history of this reservoir to be identified. To prevent the silting up of water bodies in similar environments, annual flushes or draw-off of floods with high suspended sediment loads should be considered within the operating schemes.

To provide sedimentation rates using ${ }^{137} \mathrm{Cs}$ as a time- 
marker and, due to the high cost of coring expeditions, efforts should concentrate on collecting the cores from the more stable areas in the reservoir, avoiding those prone to strong re-mobilisation. Stable areas accumulate the most complete sedimentary sequence and potentially could contain the two ${ }^{137} \mathrm{Cs}$ maxima.

In reservoirs located in Mediterranean environments characterised by high sedimentation rates as well as large variations in grain size, measurement of the detailed ${ }^{137} \mathrm{Cs}$ activity profile allows discrimination of the two maxima from any small change due to covariation with grain size.

\section{Acknowledegements}

The financial support provided by the Confederación Hidrográfica del Ebro and the Spanish Ministry of Environment for this research is gratefully acknowledged. ${ }^{137}$ Cs was analysed at the Department of Geography of the University of Exeter (UK). Special thanks are due to Prof. D. Walling and Dr. T. Quine for their support and valuable comments on this work.

\section{References}

Cambray, R.S., Playford, K. and Lewis, N.J., 1983. Radioactive fallout in air and rain: results to the end of 1982. U.K. Atomic Energy Authority Rep. AERE-R-10859. U.K. AERE, Harwell, UK.

CEDEX, 1995. Reconocimientos sedimentológicos de embalses: embalse de Barasona. Ministerio de Obras Públicas, Transportes y Medio Ambiente. Clave CEDEX: 42-493-1-052,144pp.
Davis, R.B., Hess, C.T., Norton, S.A., Hanson, D.W., Hoagland, K.D. and Anderson D.S., 1984. ${ }^{137} \mathrm{Cs}$ and ${ }^{210} \mathrm{~Pb}$ dating of sediments from soft-water lakes in New-England (USA) and Scandinavia, a failure of ${ }^{137} \mathrm{Cs}$ dating. Chem. Geol., 44, 151185.

Fargas, D., Martínez, J.A. and Poch, R.M., 1996. Identification of critical sediment source areas at regional level. Ann. Geophys., 14 (Suplement II), 314, European Geophysical Society C.

Foster, I.D.L. and Walling, D.E., 1994. Using reservoir deposits to reconstruct changing sediment yields and sources in the catchment of the Old Mill Reservoir, South Devon, UK, over the past 50 years. Hydrolog. Sci. J., 39, 347-368.

Navas, A., Valero, B., Machín, J. and Walling, D., 1998. Los sedimentos del embalse de Joaquín Costa y la historia de su depósito. Limnética, 14, 93-112.

Ritchie, J.C. and McHenry, J.R., 1990. Application of radioactive fallout cesium-137 for measuring soil erosion and sediment accumulation rates and patterns: a review. J. Environ. Qual., 19, 215-233.

Valero Garcés, B.L., Navas, A. and Machín, J., 1996. Análisis sedimentológico del pantano de Barasona, Huesca. Cadernos Laboratorio Xeolóxico de Laxe, 21, 483-493.

Valero Garcés, B.L., Navas, A. and Machín, J., 1997. Sediment deposition in the Barasona reservoir (central Pyrenees, Spain): temporal and spatial variability of sediment yield and land use impacts. IAHS Publ. no. 245, 241-249.

Valero Garcés, B.L., Navas, A., Machín, J. and Walling, D.E., 1999. Sediment sources and siltation in mountain reservoirs: a case study from the Central Spanish Pyrenees. Geomorphology, 28, 23-41.

Whicker, J.J., Whicker, F.W. and Jacobi, S., 1994. ${ }^{137}$ Cs in sediments of Utah lakes and reservoirs: effects of elevation, sedimentation rate and fallout history. J. Environ. Radioactiv., 23, 265-283.

Zucker, C.L., Olsen, C.R., Larsen, I.L. and Cutshall, N.H., 1984. Inventories and sorption-desorption trends of radiocesium and radiocobalt in James River estuary sediments. Environ. Geol. Water Sci., 6, 171-182. 